\title{
A eutanásia e os paradoxos da autonomia
}

\section{Euthanasia and the paradoxes of autonomy}

Abstract The principle of respect for autonomy has proved very useful for bioethical arguments in favor of euthanasia. However unquestionable its theoretical efficacy, countless aporiae can be raised when conducting a detailed analysis of this concept, probably checkmating it. Based on such considerations, this paper investigates the principle of autonomy, starting with its origins in Greek and Christian traditions, and then charting some of its developments in Western cultures through to itsmodern formulation, a legacy of Immanuel Kant. The main paradoxes of this concept are then presented in the fields of philosophy, biology, psychoanalysis and politics, expounding several of the theoretical difficulties to be faced in order to make its applicability possible within the scope of decisions relating to the termination of life. Key words Bioethics, Euthanasia, Death, Autonomy
Resumo 0 princípio de respeito à autonomia tem se mostrado muito útil para a argumentação bioética em favor da eutanásia. Sem embargo, a despeito de sua inquestionável eficácia teórica, inúmeras aporias podem ser levantadas, no momento em que se procede a uma análise rigorosa deste conceito, sendo possível colocá-lo em xeque. Com base nesta ponderação, o presente artigo busca investigar o princípio de autonomia, partindo desuas origens nas tradições grega e cristã e mapeando alguns desdobramentos na tradição ocidental, até sua formulação na modernidade, legado de Immanuel Kant. A seguir, são apresentados seus principais paradoxos, no âmbito da filosofia, biologia, psi canálise e política, expondo-se, assim, várias das dificuldades teóricas que precisam ser enfrentadas, a fim de tornar possível sua aplicabilidade no âmbito das decisões relativas ao fim da vida.

Palavras-chave Bioética, Eutanásia, M orte, Autonomia
${ }^{1} N$ úcleo de Estudosem Filosofia eSaúde, Centro Universitário Serra dos Órgãos. Av. Alberto Torres 111, Alto. 25964-000 Teresópolis RJ. anaximandro@hotmail.com ${ }^{2}$ Departamento de Ciências Sociais, Escola Nacional de SaúdePública, Fundação Oswaldo Cruz. 
Introdução

O Universo é como o fole de uma forja,

Que, embora vazio, fornece força,

E tanto mais alimenta a chama quanto mais o acionamos.

Quanto mais falamos no Universo,

M enos o compreendemos.

0 melhor é auscultá-lo em silêncio.

Tao Te Ching

A eutanásia éum dos temas quevem ganhando importante espaço nas discussões contemporâneas em diferentes sociedades ${ }^{1,2}$, especialmente a partir da segunda metade do século XX, momento histórico no qual "entra em cena" a bioética. Esta disciplina, que se propõe a investigar a moralidade dos atos humanos que podem alterar, de forma significativa e irreversível, os sistemas autopoiéticos, também irreversíveis, representados pelos seres vivos ${ }^{3}$, vem se debruçando sobre toda sorte de conflitos e dilemas que emergem no binômio vida/morte, mais precisamente em relação à finitude e ao significado da expressão morrer bem - daí o termo eutanásia. De fato, etimologicamente, este vocábulo diz respeito à boa morte $^{4}$, podendo ser caracterizada atualmente como a abreviação do processo de morrer deum enfermo, por ação ou não-ação, com o objetivo último de aliviar um grande e insuportável sofrimento.

0 debate bioético hodierno sobre a boa morte repousa, em grande medida, na polarização entre os princípios do respeito à autonomia individual e da sacralidade da vida, o primeiro de "inspiração" marcadamente iluminista e o último, de tessitura preponderantemente religiosa, especialmente judaico-cristã ${ }^{5}$. Embora pareça moralmente contra-intuitivo, ao menos para os defensores do princípio da sacralidade da vida, a eutanásia é moralmente defensável - no contexto das sociedades democráticas contemporâneas laicas e plurais - , na medida em que o titular da existência é o mais indicado para (auto)determinar o curso do seu viver, aqui incluído o momento e o modo no qual este se finda, ou seja, a pessoa autônoma é "em princípio a mais qualificada para avaliar e decidir o rumo de sua vida, desde que possa ser considerada cognitiva e moralmente competente" ${ }^{\prime \prime}$.

A despeito de sua relevância teórica para as discussões bioéticas - tanto às relativas ao fim da vida, quanto aos outros âmbitos deste saber $^{7,8,9,10}$ - o conceito de autonomia é complexo e é de difícil aplicação aos conflitos edilemas do mundo da vida, tal qual demonstrado por diferentes autores, $9^{911,12,13}$, pois vem sendo questionado em diferentes ordens discursivas - filosofia, neurociências, genética, psicanálise e teoria política, somente para mencionar algumas das mais relevantes - , colocando em xequesua possibilidade de fundamentar o discurso e a ação moral, de forma racional.

Com base nestas premissas, torna-se legítima a indagação acerca do alcance do princípio de autonomia da pessoa nas controvérsias morais em torno da eutanásia, em um movimento de retomada de discussões já conduzidas outro$\mathrm{ra}^{14}$. Caracterizar os elementos que entram em jogo na formulação deste problema é, assim, 0 escopo do presente artigo.

\section{As"origens" da autonomia}

0 mais arcaico emprego da palavra autonomia

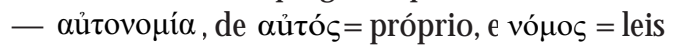
- remonta à Antigüidade grega, na referência à perspectiva de autogoverno das $\pi$ ó $\lambda \varepsilon 1 \varsigma$ (póleis = cidades-estado), surgidas por volta do século VIII a.C. ${ }^{15}$. A despeito desta acepção política originária, já florescem algumas tímidas referências à aplicação da autonomia à condição do homem ${ }^{16}$, especialmente manifestas nos sentidos de

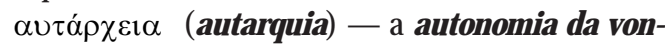

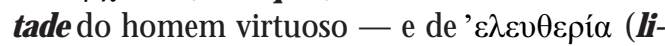
berdade) - domínio de si, caracteristicamente no âmbito da subserviência da animalidade à razão, algo também identificável no vocábulo 'Eүкрó́tı (autodomínio) - , ambos presentes na "fundação" da moral socrática ${ }^{17,18}$, centrada na idéia de alma ${ }^{19,20}$. Sem embargo, ao contrário do que uma leitura superficial - e precipitada - poderia sugerir, a vontade não é aqui entendida no sentido coevo, mas sim em concordância com certa ênfase dada ao horizonte do lógos:

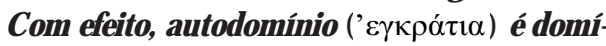
nio não da vontade, mas da razão e do conhecimento sobre os impulsos sensíveis; a liberdade

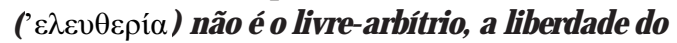
querer, mas a liberdade do lógos, ou seja, a capacidade da razão de impor as próprias instâncias às instâncias da animalidade humana. E a autarquia, como independência das necessidades animais, é, também ela, auto-suficiência do logos humano ${ }^{18}$.

Tal acento "individualista" encontra-se ainda bastante incipiente no âmbito da cultura helênica, na medida em queéreconhecida a prioridade da ordem da phýsis - o cosmo - e das leis da

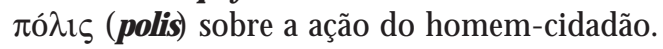


Assim, pois, a noção de autonomia aplicada ao homem poderia ser mais apropriadamente esquadrinhada em outro nicho antigo, o cristianismo primitivo ${ }^{21}$. Já nas primeiras comunidades cristãs, celebrava-sea igualdade entre os homens, na medida em que estes, por terem sido criados como almas individuais, à imagem e semel hança de Deus, pertencem, em igual medida, ao plano e à obra do $\mathrm{Pai}^{22}$. Ademais, os humanos possuem o livre-arbítrio para abrir-se e aderir, ou não, aos ensinamentos do Cristo - como na parábola das boas ou más sementes, respectivamente - , algo que é marcante no pensamento de Santo Agostinho ${ }^{23}$, o primeiro filósofo da vontade $e^{24,25}$.

Se a autonomia pode ser "buscada", sob um ponto de vista histórico-conceitual, entre as tradições helênica e cristã ${ }^{26}$, será com 0 advento da modernidade queo indivíduo, indiviso, se constituirá como eu pessoal, capaz de conhecer o mundo (sujeito epistêmico) edeagir autonomamente no âmbito da ética (sujeito moral), erigindo os valores que nortearão o julgamento ea práxis em sua vida social ${ }^{27}$. Foram as coordenadas espaçotemporais propícias - o humanismo renascentista, a reforma protestante, a revolução científica e a redescoberta do ceticismo antigo - que permitiram a construção do indivíduo moderno ${ }^{28,29}$.

0 primeiro grande movimento neste sentido foi realizado por René Descartes, o qual, a partir deuma dúvida radical sobretoda equalquer possibilidade de conhecimento ${ }^{30}$, chega à proposição de uma substância pensante - a res cogitans, em oposição à substância do mundo, a res extensa , caracterizável como uma realidadeimediatamentedada a um sujeito querefletesobresi mesmo ${ }^{10,31}$. Assim, pois:

De sorte que, após ter pensado bem nisso e ter cuidadosamente examinado todas as coisas, é preciso enfim concluir eter por constante queesta proposição, Eu sou, eu existo, é necessariamente verdadeira todas as vezes que a pronuncio ou que a concebo em meu espírito ${ }^{31}$.

A certeza procurada por Descartes é "entrincheirada" neste eu pensante - racional e dotado de idéias claras e distintas - , havendo a necessidade deserecorrer a Deus para que tal solipsismo radical possa ser, enfim, superado ${ }^{31}$. Neste "esquema trinitário" - res cogitans / Deus / res extensa - , o espaço para a liberdade permanece resguardado, na medida em que o filósofo reconhece que "a principal perfeição do homem está em dispor de um livre-arbítrio" 32.

0 racionalismo cartesiano foi alvo deinúmeras críticas, podendo-se mencionar os questionamentos formulados por David Hume, em re- lação à identidade pessoal. 0 pensador escocês critica o modelo cartesiano, afirmando que não é possível haver qualquer representação da mente de forma independente da experiência - ou seja, não há como representar o pensamento puro. 0 "eu" passa a ser entendido como um "feixe" de percepções, inscrito em um dado momento, que pelo hábito - econtinuidade - adquire um statusindividual:

Há alguns filósofos queimaginam que estamos a todo momento conscientes de algo a que chamamos nosso 'eu' (Self) eque sentimos a sua existência contínua, tendo certeza, para além de qualquer evidência e demonstração, de sua perfeita identidade e simplicidade. [...] M as o eu ou pessoa não é uma impressão determinada, mas aquilo que se supõe que nossas várias impressões ou idéias têm como referência. Sealguma impressão dá origem à idéia de eu, essa impressão deve manter-se invariavelmentea mesma, durantetodo o curso denossas vidas, uma vez que se considera que o eu existe desta maneira. M as não há nenhuma impressão constante e invariável. D or e prazer, tristeza e alegria, paixões e sensações sucedem-se umas às outras, enunca existem todas ao mesmo tempo. Não pode ser, portanto, de nenhuma dessas impressões, nem denenhuma outra, quea idéia deeu éderivada, e conseqüentemente esta idéia simplesmente não existe ${ }^{33}$.

Como pode ser percebido, a refutação do eu efetuada por Hume é devastadora. Uma "resposta" possível foi apresentada por Immanuel Kant, ao introduzir o conceito de sujeito transcendental, na Crítica da razão pura - tornando-o antes uma forma que estrutura as percepções do queum conteúdo dotado de realidade própria - , obra que expõe uma teoria do conhecimento, a qual, em última análise, busca uma composição dos impasses existentes entre o empirismo e o racionalismo ${ }^{34}$.

A bela "saída" encontrada por Kant para a questão do conhecimento facultou a extensão da centralidade do sujeito transcendental ao âmbito moral, o que permitiu a concepção do sujeito ético, moralmente autônomo, como o discutido a seguir.

\section{Autonomia: o fundamento da moral}

A aplicação definitiva do conceito de autonomia moral ao indivíduo - um necessário "produto" da modernidade burguesa e protestante ${ }^{35}-$, iniciada com o pensamento moderno e consolidada no projeto daAufklärung (Iluminismo), ganha sua expressão máxima na formulação moral siste- 
mática de Kant, na Fundamentação da metafísica dos costumes e na Crítica da razão prática ${ }^{36,37}$.

Para o filósofo germânico, a moralidade é a única condição capaz de tornar o homem, ser racional, um fim em si mesmo $0^{37}$. Tal éa prerrogativa do ser dotado de razão, constituído como sujeito moral - pessoa - , capaz de agir por dever, este entendido como "a necessidade de cumprir uma ação por respeito à lei" ${ }^{37}$, na medida em que esta é universal - ou seja, capaz de ser erigida a norma geral einequívoca ${ }^{38}$, como diz o próprio pensador: "Procede apenas segundo aquela máxima, em virtude da qual podes querer ao mesmo tempo que ela se torne em lei universal" 37.

É preciso pontuar quea aquiescência em agir por dever à lei universal é, em última análise, uma ação inscrita na boa vontade (das guteWille):

“É absolutamente boa a vontade que não pode ser má, portanto aquela vontade, cuja máxima, quando convertida em lei universal, não pode jamais contradizer-se a si mesma" ${ }^{37}$.

Reconhecer - eaderir incondicionalmentea - este imperativo categórico é um ato genuinamente moral, somente podendo ser alcançado por um ser racional e autenticamente autônomo, concorde com a boa vontade:

A moralidade é pois a relação das ações com a autonomia da vontade, isto é, com a legislação universal possível por meio das suas máximas. A ação que possa concordar com a autonomia da vontadeé permitida; a que com ela não concordeé proibida. A vontade, cujas máximas concordem necessariamente com as leis da autonomia, é uma vontade santa, absolutamente boa ${ }^{37}$.

Torna-se diáfana a posição adotada por Kant, entender a autonomia como o princípio supremo da moralidade - em contraposição à heteronomia, não advinda da vontade livre, produtora, por contraste, de imperativos hipotéticos - , na medida em que esta, por fim, possa ser compreendida como:

"[...] não escolher se não de modo a que as máximas da escolha estejam incluídas, simultaneamente, no querer mesmo, como lei universal" ${ }^{37}$.

0 universalismo categórico da filosofia moral kantiana permaneceatéo final do século XIX, momento no qual as mordazes censuras impostas por Schopenhauer, Nietzsche e Freud e, posteriormente, já no século XX, a transformação da moral em ética aplicada - marcada pela "substituição" dos deveres absolutos por deveres prima facie - , colocam sua formulação original em xeque. Ainda assim, a autonomia - juntamente com a justiça - , manteve- se como grande ideário norteador da construção da cidadania no século passado, no contexto das sociedades democráticas, laicas e plurais contemporâneas ${ }^{39}$.

Acrescente-se a isto o fator de boa parte da reflexão moral dosúltimos 38 anos - coincidente com o advento da bioética - , ter se estribado em um conceito de respeito (prima facie) à autonomia individual, como aquele formulado no âmago do principialismo ${ }^{7}, 0$ qual considera autônomo o indivíduo que "[...] agelivrementedeacordo com um plano escolhido por ele mesmo, da mesma forma que um governo independente administra seu território e define suas políticas" 7 .

A autonomia para agir livremente de acordo com um plano escolhido por elemesmo deveincluir, em tese, todas as decisões concernentes à existência do indivíduo, inclusive a deliberação por encerrá-la, abrindo-se assim espaço para as discussões em torno da moralidade da boa morte.

\section{Autonomia:}

\section{o esteio para a moralidade da eutanásia}

0 princípio derespeito à autonomia têm fornecido sustentação a cogentes argumentos bioéticos em defesa da eutanásia5. N este âmbito, é mister que seja respeitada a liberdade de escolha do homem que padece, isto é, sua competência em decidir, autonomamente, aquilo que considera importante para viver sua vida, incluindo nesta vivência o processo de morrer, de acordo com seus valores e interesses legítimos. Deste modo, com raízes fincadas na Antigüidade - espírito helênico ecristianismo - epleno florescimento na Aufklärung, o respeito à autonomia pressupõe que cada indivíduo tem o direito de dispor desua vida da maneira que melhor the aprouver, optando pela eutanásia no exaurir de suas forças, quando sua própria existência se tornar subjetivamente insuportável:

Em tal sentido, podese dizer que, em caso de confli to de interesses e de direitos, o direito da autodeterminação tem uma prioridade léxica sobre os demais direitos no contexto de decisões referentes à vida eà morte de seu titular, quer dizer, a pessoa em princípio é mais qualificada para avaliar e de cidir o rumo de sua vida 6 .

Nesteâmbito, concebe se uma genuína pree minência do titular da existência para decidir (1) tanto não permanecer em um martírio que não 0 conduziráa lugar algum, a não ser à própria morte, (2) quanto continuar padecendo, não por uma decisão tomada por outrem, mas, sim, por uma opção pessoal, que pode até ser a de se submeter, por boas razões, à imposição de um outro. 
Sem embargo, a despeito de sua eficácia teórica na argumentação bioética sobre o fim da vida, o princípio deautonomia podeser questionado a partir de distintas frentes, emergindo paradoxos - no sentido grego de $\pi \alpha \rho \alpha ́ \delta$ o que se opõe à opinião comum ${ }^{40}-$ que podem, mesmo, inviabilizar sua aplicação. Vejam-se um pouco mais de perto tais aporias.

\section{Primeiro paradoxo: acaso ou necessidade?}

Pode-se dizer que o correspondente ético do debate epistemológico acaso/necessidadeé o par antagônico livre-arbítrio/determinação. Em última análise, a compreensão da realidade enquanto manancial sujeito à determinação éinstaurada nos próprios primórdios do pensamento grego ${ }^{41}$.

Defato, para Anaximandro, a origem ea corrupção do cosmo éestabel ecida segundo a necessidade ${ }^{42}$, ou seja, respeitando à determinação constitutiva do próprio processo. Tal perspectiva está inscrita no espesso tecido do espírito helênico ${ }^{43}$, mormente se é reconhecido o papel do destino ( M oiras = Moî́aı ) nos mitos homéricos ehesió$\operatorname{dicos}^{43}$, na tragédia - como no caso paradigmático de Édipo que, ao tentar fugir de seu destino parricida, acaba encontrando, justamente, o sangue de seu pai, Laio ${ }^{44}$ - ena medicina hipocrática - na concepção de queal gumas doenças são frutos da ananke (' $\alpha v \alpha ́ \gamma \chi \eta)$, necessidade inflexível ${ }^{45}$. Esta influência - baseada em uma composição de conceitos não completamente sobreponíveis, mas relacionáveis, como determinação, necessidadeedestino - éreconhecida por EtienneGilson ao comparar as filosofias gregas e cristãs:

[...] influenciadas pela religião grega, as filosofias gregas são filosofias da necessidade, ao passo que as filosofias influenciadas pela religião cristã serão filosofias da liberdade ${ }^{25}$.

É preciso comentar, no entanto, a exceção feita ao atomismo de Epicuro, um esforço para pensar o acaso e a liberdade, o que é retomado pelo filósofo latino Lucrécio ${ }^{46,47}$. Para os atomistas em questão, o que torna possível o real (ontologia) e a liberdade (ética) éo clinamen, o desvio - ou declinação - dosátomos, o qual ocorre por acaso ${ }^{48}$, individualmente para cada uma das partículas ${ }^{49}$, em um momento e em um tempo que são impossíveis de predizer e/ou determinar ${ }^{47}$. Tal é o fundamento do cosmo e do livrearbítrio.

O contraponto ao epicurismo é dado por uma modelar filosofia da necessidade, construída pela escola de Zenão de Cicio; trata-se do es- toicismo 50,51 . O pensamento estóico é concebido de forma sistemática, em três partes, de acordo com a metáfora da árvore: a física (raiz), a lógica (tronco) e a ética (os frutos) - sendo esta última a demaior importância, masinal cançável sem as duas anteriores ${ }^{50}$.

Para os estóicos, o cosmo tem dois princípios, o passivo e o ativo. 0 primeiro é a matéria, e o segundo, a razão que naquela se encontra, Deus, o logos spermatico - ou razão seminal - do mundo, que contém em si as razões de todas as coisas $^{52}$. Assim, Deus forma uma unidade com 0 cosmo. Ademais, os estóicos defendem as idéia de eterno retorno cíclico do universo, dentro de um esquema de determinação radical - ou seja, todas as coisas acontecem fatalmente, a partir de uma inextirpável concatenação causal, a qual governa 0 mundo ${ }^{51}$. N este horizonte, o homem deve se resignar a aceitar a determinação do mundo - nisto se funda a ética - , agindo de acordo com preceitos morais julgados pertinentes, mas reconhecendo as conseqüências de sua ação ea inevitabilidade dos fatos. A ceitar o destino deste modo incondicional é uma atitude de ataraxia (imperturbabilidade), chave para o alcance da eudaimonia (felicidade).

Esta perspectiva determinista ganhou marcanteressonância no pensamento de Baruch Spinoza, para o qual Deuséidentificado com a própria realidade, ou seja, Deus sive natura, em uma imanência radical ${ }^{53}$. Neste âmbito, o homem é livre - agindo eticamente - ao se pôr diantede Deus - a substância infinita - , reconhecendo sua necessidade seminal, manifesta no curso necessário das coisas ${ }^{54}$. A ação livre alicerça-se na inequívoca concordância com esta determinação universal, sendo prerrogativa da alma humana que atinge a serena tranqüilidade.

0 determinismo, marca inexpugnável das concepções dos estóicos e de Spinoza, vai alcançar seu apogeu a partir da Revolução Científica, iniciada, antes, por Galileu Galilei e consolidada por Sir Isaac N ewton. 0 físico inglês propõe um grande sistema de leis matemáticas para a explicação do mundo, as quais tornam factível a predição, a partir do estado de um dado sistema físico - posições e velocidades, as quais caracterizariam o assim chamado instante inicial — , da situação ulterior do sistema em qualquer instante $\mathrm{e}^{55}$. Assim, a partir da mecânica newtoniana, a matematização do mundo possibilita um nível antes inimaginável de previsibilidade do real, a ponto de o físico, em seus Princípios M atemáticos de Filosofia N atural, ${ }^{56}$ pontuar que:

Gostaria que pudéssemos derivar o resto dos 
fenômenos da natureza pela mesma espécie de raciocínio a partir de princípios mecânicos, pois sou levado por muitas razões a suspeitar quetodos eles podem depender de certasforças pelas quais as partículas dos corpos, por causas até aqui desconhecidas, são ou mutuamente impelidas umas para as outras, e convergem em figuras regulares, ou são repelidas, e afastam-se umas das outras ${ }^{56}$.

Não é difícil supor o quanto esta prerrogativa tornou possível a concepção de que o universo já se encontrava praticamente desvendado, a partir do (re)conhecimento de suas leis naturais - o que, diga-se de passagem, pode ser recuperado a partir do estoicismo. 0 ideário determinista chega a alcançar um grau de pujança tão sólida e inabalável, que o matemático Pierre Simon Laplace ${ }^{57}$ chega a afirmar:

U m intel ecto que, em um momento dado qualquer, conhecesse todas as forças que animam a $N$ atureza eas posi ções mútuas dos seres que a compõem, se esse intelecto fosse vasto o suficiente para submeter seus dados a análise, seria capaz de condensar em uma única fórmula o movimento dos maiores corpos do universo e o menor dos átomos: para tal intelecto nada poderia ser incerto; etanto o futuro quanto o passado estariam presentes diante de seus $\mathrm{olhos}^{57}$.

Com tal nível de agudeza, fica fácil compreender que o determinismo laplaciano não deixa espaço para o acaso e, tampouco, para o livrearbítrio ${ }^{58}$. Entretanto, alterações no panorama das teorias físicas e matemáticas no século XX acabaram por forçar a revisão deste paradigma. 0 advento da mecânica quântica foi decisivo neste sentido, ao colocar em questão a causalidade e o determinismo na compreensão da natureza $a^{59,60}$, representando um duro "golpe" em toda uma tradição de pesquisa que se ancorava na pretensa investigação das leis deterministas do mundo objetivo - ou seja, referida a processos físicos que têm lugar no espaço e no tempo - , independentes de quem investiga (isolando, pois, observador e observado).

Muitos pensadores contemporâneostêm identificado a emergência da física quântica como uma demonstração cabal de que a necessidade é uma simples quimera que deixou de fazer sentido, especialmente após a enunciação do Princípio da Incerteza de Heisenberg ${ }^{61,62}$. Sem embargo, tal posicionamento é equívoco - ou, pelo menos, insuficiente - por pelo menos três motivos:

(1) A física quântica refere-se ao microcosmo, o qual "escapa" à possibilidade de experiência corriqueira do homem, ao passo que a mecânica newtoniana permanece extremamente útil para compreender o mundo ordinário de todos os dias - construir prédios, enviar o homem à lua, e outros ${ }^{63}$;

(2) A indeterminação vem sendo revista a partir do desenvolvimento da matemática do caos, enquanto elegante tentativa para integrar ordem e acaso; neste referencial, o caos é entendido como o "comportamento estocástico que ocorre em um sistema determinístico" ${ }^{64}$, ou seja, como um ruído presente em um sistema marcado pela necessidade - 0 exemplo mais claro, e simples, é a iteração de $2 x^{2}-1$ (Figura 1) -, como bem caracterizado por David Ruelle ${ }^{58}$ :

Fala-se também de ruído determinista quando se observam oscilações irregulares de aparência aleatória, mas que são produzidas por um mecanismo determinista. N os fenômenos caóticos, a ordem determinista cria, portanto, a desordem do acaso ${ }^{58}$.

A aplicação do caos clássico, assim entendido, vem sendo tentada no âmbito do mundo quântico, fazendo com que seja possível antever a superação da indeterminação do microcosmo - quiçá como o sonhado por Einstein. Ainda que se esteja, do ponto de vista teórico, distante de tal perspectiva, tal alcance é vislumbrado pelos matemáticos:

Há sempre uma possibilidade de que alguma nova versão da mecânica quântica venha substituir a natureza probabilística da função de onda por algo determinístico, mas caótic $0^{64}$.

Neste sentido, mesmo que "Deus jogue dados", poder-se-á chegar à resposta acerca das regras segundo as quais o Seu jogo é realizado;

(3) Por fim, restará sempre a possibilidade de a indeterminação ser, em última análise, uma conseqüência da ignorância humana acerca das causas. Assim, pois, para Spinoza, as causas são da ordem do infinito e, por conseguinte, imperscrutáveis pela mente humana ${ }^{53}$. É precisamente neste sentido que se estabelece 0 determinismo de Henri Atlan ${ }^{65}$ :

$N$ ossas noções de entropia e ruído são derivadas de noções estatísticas. $E$, portanto, mais uma vez, não contradizem a idéia do determinismo absoluto. Elas são medidas da nossa ignorância. $M$ as é óbvio que, embora não contradigam o determinismo absoluto, nada provam acerca dele. Esta éa clássica questão da natureza do acaso: será ele intrínseco, ontológico, ou atribuível apenas à nossa ignorância?65

A formulação de Atlan - a qual, de certo modo, reatualiza a polêmica epicuristas versus estóicos - permanece longe de ser respondida. N estes termos, pensar a autonomia enquanto livre-escolha permanece algo da ordem do possí- 
Figura 1. A iteração de $2 x^{2}-1$ conduz ao caos.

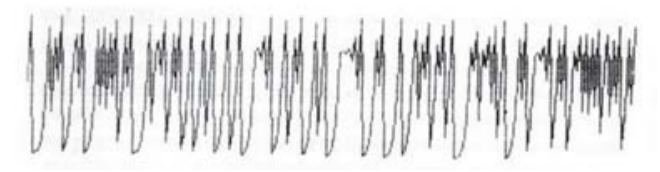

vel, mas sempre com a "sombra" irremovível de uma necessidade, quase destino, que subtrai toda e qualquer possibilidade de decisão autônoma, quer sobre a vida, quer sobre a morte.

Segundo paradoxo: o "caso" da biologia neurociências e genética

A questão das neurociências e da genética reatualiza, de um modo próprio, o debate determinismo versus liberdade ${ }^{66}$. Em verdade, 0 que está em jogo é a limitação imposta pela própria biologia humana, na medida em quea existência material - ou corpórea - marca, demodo indelével, toda sorte de restrições, como cansaço, senescência, enfermidade, sofrimento e morte, as quais têm profunda influência sobrea (im)possibilidade de autodeterminaçãa ${ }^{39}$.

As neurociências - conjunto de saberes, de matriz multi einterdisciplinar, quese dedicam ao estudo dos órgãos que compõem o sistema nervoso central, em especial o cérebro - , vêm contribuindo deforma significativa, nosúltimoscinqüenta anos, para a compreensão dos processos mentais ${ }^{67,68}$, dentro de uma perspectiva teórica que propõe a redução destes processos à simples atividade neuronal ${ }^{69,70}$. Um dos marcos históricos nestas investigações é o famoso "caso Phineas Gage", ocorrido no século XIX. Gage, um operário-padrão - dono de um comportamento exemplar, como atestam diferentes fontes históricas $^{67}-$, sofreu um acidente caracterizado pela penetração de uma barra de ferro na região infra-ocular, a qual emergiu na parte posterior do osso frontal. Tendo sobrevivido ao evento, o enfermo passou a apresentar um comportamento irascível, marcado por explosões de raiva e por profunda irreverência; ademais, perdeu a capacidade dearticular idéias e de planejar suas ações, com profundas implicações sobre suas tomadas de decisão ${ }^{67}$. A partir de então, inúmeras situações semel hantes foram tornadas públicas na literatura médica internacional, a ponto desta re gião cerebral - o setor ventromedial do córtex pré-frontal - passar a ser "responsabilizada" por diferentes comportamentos "anti-sociais" e patológicos, culminando na proposição, e realização, decirurgias mutilantes - a psicocirurgia em pacientes psiquiátricos (esquizofrênicos, sobretudo) e delinqüentes "rebeldes".

Atualmente, as pesquisas voltam-se para a identificação dos circuitos responsáveis pelas atividades de planejamento etomada de decisão, os quais são esboçados na Figura $2^{71}$.

Ainda que estes trabalhos estejam em fase bastante inicial, o que está em jogo é a discussão sobre até que ponto os eventos bioquímicos e moleculares cerebrais são responsáveis pelo ou determinantes do - julgamento de possibilidades e pela tomada de decisões - evidentemente, desde que se aceite que a ciência é realmente capaz de descrever a realidade - tornando o livre-arbítrio uma simples ilusão gerada pela arquitetura cognitiva ${ }^{72}$.

Neste mesmo plano de confluência teórica se inscrevem os debates sobre a determinação ge nética do ser humano e de sua vontade. Um dos exemplos mais estarrecedores é o da doença de $H$ untington, enfermidade genética autossômica dominante, que ocorre por repetições do trinucleotídeo CAG no genelT15, localizado no braço curto do cromossomo $4^{73}$. A moléstia tem penetrância completa, demodo que todos aquel es que possuem a alteração genética desenvolverão suas manifestações, mais cedo ou mais tarde, na dependência do número de repetições CAG existentes. Por outro lado, aqueles indivíduos que apresentem trissomia da banda cromossômica 21q22 exibirão necessariamente a síndrome de Down, enquanto uma duplicação de cromossomos X em associação a um Y (cariótipo XXY) determinará a síndrome de K linefelter.

Há uma determinação genética absoluta nestes casos? Ao que parece, sim, na medida em que as observações real izadas até o presente momento corroboram tais resultados, colocando em questão toda a polêmica acerca do determinismo genético ${ }^{74,75}$, modelo segundo o qual "os genes possuem a explicação final para muitas características dos organismos vivos"75. Sem embargo, esta perspectiva reducionista - o homem restringido aos seus genes - é fortemente contestada por uma série de evidências científicas ${ }^{76}$. Assim, pois:

0 s genes são certamente importantes para determinar a identidade biológica do indivíduo humano, masnão são tudo para determinar a identidade de um indivíduo, visto que determinam uma limitação do possível mas dificilmentedeterminam, sozinhos, um destino $0^{77}$. 
Figura 2. É possível propor uma "neuroanatomia" da tomada de decisão envolvendo o córtex pré-frontal? Recentes investigações têm corroborado esta hipótese. N este contexto, o uso da razão se iniciaria medialmente pela atuação do córtex cingulado anterior (atenção executiva), o qual tem por função focalizar a atenção perceptual e cognitiva, modulando a atividade das áreas correspondentes. As regiões dorsolaterais do córtex pré-frontal seriam responsáveis pela comparação das informações, novas e as antigas. 0 derradeiro ajuste levando em consideração os objetivos dos indivíduos e os contextos sociais - seria realizado por uma área não ilustrada, o córtex pré-frontal ventromedial. Imagem neuroanatômica preparada por Rodrigo Siqueira-Batista (UNIFESO) e Vanderson Esperidião Antonio (UNIFESO), sob inspiração de Posner MI, Raichle ME. Images of mind. New York: Scientific American Library; 1994.

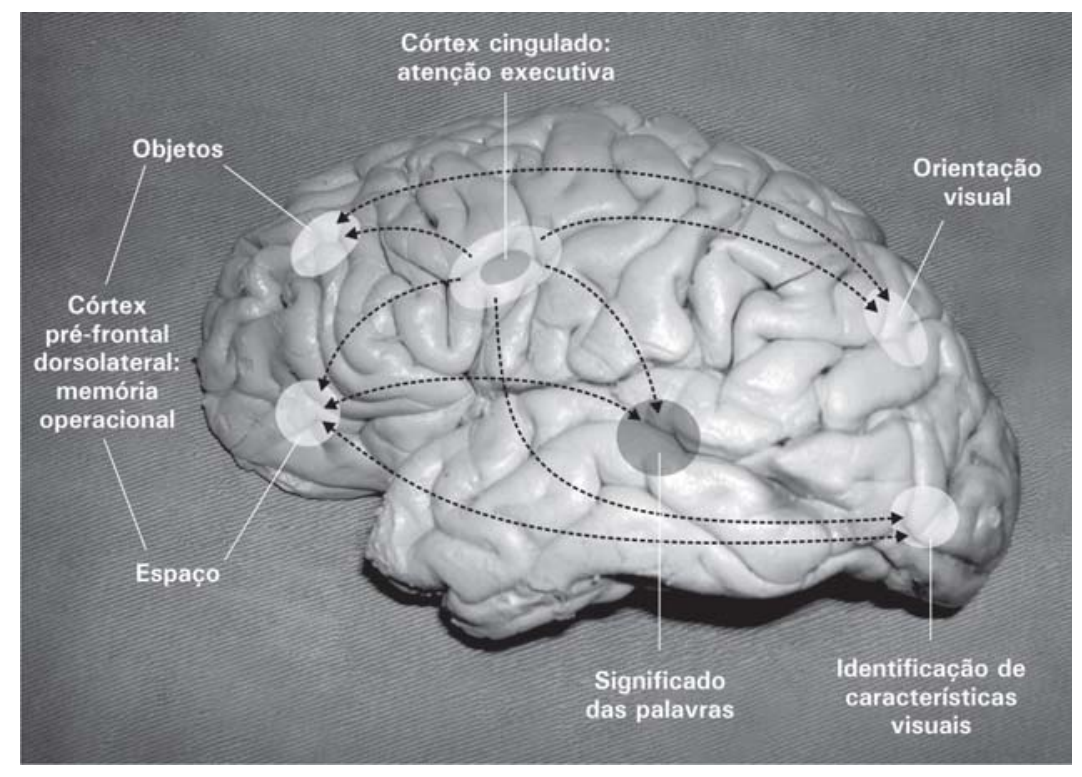

Não é difícil compreender tal ponderação, à luz da distinção entre as duas "naturezas" humanas: bi oecológi ca ou "primeira natureza", propriamente natural; e técnico-lingüística ou "segunda natureza", engendrada no plano simbólico, as quais interagem ese condicionam fluida emutuamente $^{78}$. Em última análise, não parece ser possível defender quea primeira determine peremptoriamente a segunda, na medida em que ambas são dimensões distintas, ainda que solidárias na constituição do Homo sapiens sapiens.

M esmo queo determinismo genético possa ser rechaçado, a questão da necessi dade permaneceem aberto, na medida em quea combinação do patrimônio genético e das condições materiais de existência (para lembrar M arx) de uma pessoa poderiam estipular seu desenvolvimento, de modo irrevogável ${ }^{79}$.

Com base nestas considerações, percebe-se que todo este tecido, composto a partir dos discursos relativos à biologia [humana], parece remeter a uma situação de impossibilidade de li- vre-arbítrio, como na afirmação de Erasmo G. Mendes ${ }^{80}$ :

[...] esses resultados [da neurofisiologia e da genética] indicariam fortemente uma predeterminação do comportamento humano, dificultando a aceitação deuma liberdadeda vontade, nos moldes em que ela é tradicionalmente aceita por muitos estudiosos ${ }^{80}$.

\section{Terceiro paradoxo: Schopenhauer,} Nietzsche, Freud e o inconsciente

O grande edifício teórico proposto por Kant desempenhou um papel decisivo no pensamento ulterior, com inquestionável influência na filosofia dos séculos XVIII e XIX, especialmente nas questões epistemológicas - como no caso do construtivismo - mas, também, nas discussões em âmbito moral, como anteriormente apresentado. Sem embargo, diferentes autores questionaram os pressupostos do racionalismo ético 
kantiano, cabendo destaque a Arthur Schopenhauer, Friedrich Nietzsche eSigmund Freud, os quais merecerão breve comentário.

A principal obra de Schopenhauer, o Mundo como vontade e representação, alberga uma importantecrítica ao ideário iluminista ${ }^{81}$. 0 filósofo mantém a distinção kantiana entre fenômeno e númeno, mas caracteriza-os, respectivamente, como representação e vontade. 0 primeiro compreendea realidadeempírica, ou seja, constituída de "coisas" tais como são conhecidas pelos sentidos, as quais se originam a partir da apreensão, pelo sujeito, do mundo em si. Esteéo horizonteda Representação (Vorstellung), a qual não existe em si mesma, "apresentando-se" quando recebe sua estrutura por meio das formas cognitivas intrínsecas àquel eque conhece ${ }^{81}$. Ao contrário, o mundo em si éconstituído por uma essência intangível, a Vontade (Wille), cega e irracional - e não mais das gute Wille, a boa vontade kantiana - , que só faz desejar e querer incessantemente ${ }^{81,82}$. Tudo 0 que se apresenta como existência singular - coisaseindivíduos - possui, em última análise, uma vontade subjacente - a qual permanece após a extinção da existência individual - , matriz deum anseio inextirpável einsaciável, o qual seconstitui nos viventes como vontade de vida. Deste modo, para Schopenhauer, o elemento primário nos seres humanoséa vontade - irracional - , enão o intelecto - racional - , reconhecido como secundário e submetido à primeira ${ }^{83}$. Tal formulação é reconhecida, por alguns autores, como um gérmen da idéia freudiana de inconsciente ${ }^{84}$.

A subversão instituída por Schopenhauer torna-se clara, mesmo nesta sumária exposição. $\mathrm{Na}$ verdade, o indivíduo autônomo da moral kantiana desmorona, na medida em que (1) esteé uma efêmera organização temporal de algo muito maior, a vontade, a qual é (2) capaz de determinar - ainda que não em um esquema convencional causa- efeito - , a partir de um desejo irrefreável, suas escolhas pretensamente livres e racionais, abrindo-se (3) a perspectiva para o reconhecimento de uma instância para além da consciência, capaz de se impor a esta última. Assim, pois, em um trabalho posterior, Schopenhauer é categórico em rejeitar que o fundamento da moral esteja no uso imparcial da razão, situando-o, outrossim, no âmbito da compaixão ${ }^{85}$.

Uma substantiva apreciação da ética kantiana foi conduzida por Nietzsche, o qual, na Genealogia da $M$ oral ${ }^{86}$ eem Além do Bem e do $M$ al ${ }^{87}$, procede a uma genuína desconstrução dos pressupostos racionalistas de Kant ${ }^{9}$, na esteira de sua encarniçada crítica à metafísica clássica. No pri- meiro ensai o, o filósofo tenta "desvendar" a gênese das concepções éticas tradicionais, denunciando a "moral do rebanho", fraca, impotente e ressentida ${ }^{86}$. Na segunda obra, busca a transmutação de todos os valores, demolindo, a golpes de martelo, o pífio maniqueísmo da cultura ocidental -0 bem versus o mal - , como explícito no aforismo "O que uma época percebe como mau é geralmente uma ressonância anacrônica daquilo que um dia foi considerado bom - 0 atavismo de um antigo ideal" ${ }^{87}$. Contrapondo-se a isto, são erigidas a vontade, a criatividade e 0 sentimento estético como genuínas afirmações da vida ${ }^{87}$.

Ademais, Nietzsche também subverte completamente a idéia de das gute Wille - em certa medida na "esteira" deSchopenhauer - , demonstrando que a ela subjaz a vontade de poder e 0 ressentimento advindo deseu não alcance ${ }^{86,87}$. M ais uma vez, o indivíduo autônomo, capaz de enunciar - e aderir ao - imperativo categórico, é colocado na berlinda. Entretanto, a ruptura não é completa: a proposta nietzschiana para sobrepor 0 , ou ir além do, ressentimento - a partir da imagem do Ü bermensch, o sobre-H omem - , mantém (eagudiza) a perspectiva voluntarista da ética de Kant, ainda que atrelando o querer humano à irracionalidade (como Schopenhauer).

A despeito das anástrofes construídas por Schopenhauer eNietzsche, éapsicanálisedeFreud que descentrará definitivamente, por assim dizer, o sujeito racional kantiano de seu lugar privilegiado para o julgamento/ação moral88.

0 ponto de partida para a compreensão de uma tal assertiva éo reconhecimento da centralidade do inconsciente (das U nbewusste) na teoria psicanalítica ${ }^{89}$. A descrição do inconsciente pode ser erigida a ponto de inflexão desta descentralização do sujeito do iluminismo, na medida em que expõe, deforma virtualmente incontestável, o quão limitada é a concepção que entende os processos psíquicos apenas nos seus aspectos conscientes ${ }^{90}$ :

Assim, enquanto D escartes pensava o eu como uma entidade original, Freud o pensa como engendrado; enquanto Descartes nos fala do sujeito da ciência, Freud nos fala do sujeito do desejo. Antes de Freud o sujeito se identificava com a consciência; a partir de Freud temos que nos perguntar por esse sujeito do inconsciente e por sua articulação com o sujeito consciente ${ }^{90}$.

Defato, partindo de sua compreensão de que a distinção entre consciente e inconsciente é a matriz da psicanálise ${ }^{94}$, Freud contesta a autotransparência da razão, explicitando que as causas últimas dos atos humanos estão relacionadas 
à libido - determinada por Eros e Thanatos. Ademais, este comentário ressalta um aspecto significativo da concepção de sujeito freudiano, queéa sua clivagem em conscientee inconsciente; ou seja, trata-se de uma subjetividade cindida e instituída por duas sintaxes díspares.

Mas, qual a real dimensão do inconsciente? Freud descreve-o a partir de suas investigações sobre os fenômenos lacunares - o sonho, o lapso, 0 ato falho, o chiste e os sintomas ${ }^{90}$ - identificando seu núcleo com "impul sos car regados de desej 0 "91,92. Características importantes do inconsciente incluem a ausência de temporalidade e a existência de uma ordenação, uma sintaxe, que Lacan reconhece como linguagem ${ }^{93}$. Ademais, 0 inconscientenão podeser identificado com uma região "profunda" da consciência - obscura, instintiva e ilógica - e, tampouco, como uma substância, ou seja, não éuma "coisa" e, também, não "ocupa" um lugar. Em última análise, o inconscienteéuma forma, um modus operandi distinto da consciência, segundo o qual seus conteúdos se ordenam. Estes, por seu turno, consistem em representações (Vorstellungen), inscrições da pulsão nos sistemas psíquicos.

Tal concepção de inconsciente tem ainda como elemento fundamental a negação da pura e simples arbitrariedade dos eventos psíquicos, afirmando, a seu modo, uma modalidade de determinismo com profundas implicações nas operações conscientes:

[...] os acontecimentos psíquicos são determinados. N ão há nada arbitrário neles. Demodo bastantegeral, pode- sedemonstrar quese um elemento é deixado indeterminado por um certo encadeamento de pensamentos, sua determinação éimediatamente efetuada por um outro. Por exemplo, posso tentar pensar arbitrariamente num número, mas isso é impossível: o número que me ocorrer será inequívoca e necessariamente determinado por pensamentos meus, embora eles possam achar-se afastados de minha intenção imediata ${ }^{94}$.

Esta determinação psíquica é incompatível com a autonomia iluminista, na medida em que o inconsciente dita as preferências e opções aparentemente livres que se estabelecem como "suposto" produto da atividade consciente, a ponto de ser possível dizer que "Freud coloca por terra o livre arbítrio"11.

Mas esta não é a única determinação proposta pela psicanálise. Um outro ponto desenvolvido na segunda tópica - naqual háum "deslocamento" da antiga tríade consciente/inconsciente/pré consciente para uma nova, ego/ld /superego - é a participação do processo civiliza- dor na formação do psiquismo, em um movimento derenúncia imposta pela cultura95. 0 que merece ser destacado, no contexto desta breve discussão, é o conceito de superego, herdeiro do complexo de Édipo e modelo do superego dos pais. Freud atribui-Ihe uma tríplice função: (1) de auto-observação, (2) de ideal do ego e (3) de consciência moral ${ }^{96}$. N esteúltimo ponto, há uma tentativa, por parte do psicanalista, de identificálo com o imperativo categórico kantiano ${ }^{97}$, o que tem motivado acirradas controvérsias entre os comentaristas de Freud, alguns identificando como errônea a aproximação do psicanalista98, outros ressaltando sua relevância para compreensão do pensamento kantiano ${ }^{99}$. Pode-se argumentar que Freud "assimila" a crítica hegeliana a Kant ${ }^{100}$, no horizonte de questionamento sobre as condições para o advento da consciência/sujeito transcendental. De todo modo, o próprio Freud reconhece que seu tabu - o imperativo categórico" ${ }^{99}$ - "rejeita quaisquer motivos conscientes"97, algo afim à "leitura" realizada por Jacques Lacan: A lei moral, examinada de perto, não éoutra coi sa senão o desejo em estado puro, aquele mesmo que termina no sacrifício, propriamente falando, de tudo o que é objeto de amor em sua ternura humana ${ }^{101}$

O panorama estabelecido a partir das críticas formuladas por Schopenhauer, NietzscheeFreud alteraram, radicalmente, o ideário, até então vigente, de um sujeito capaz de pensar e a agir motivado por uma razão albergadora de idéias claras edistintas e/ ou capaz de se constituir como um verdadeiro tribunal, no qual são julgados, de forma autônoma e imparcial, os diferentes aspectos relativos ao conhecimento eà moral. Ser e pensar deixam de ser coincidentes - dimensão que pode ser recuperada na própria nascente do pensamento ocidental, em um filósofo tão originário quanto Parmênides de Eléi $a^{43}-$, a ponto de Lacan poder formular uma afirmação tão impactante - e elucidativa - quanto "penso onde não sou, portanto sou onde não penso"93.

Quarto paradoxo:

indivíduo versus coletivo

eas tensões entre autonomia ejustiça

O equilíbrio entre autonomia ejustiça nas sociedades democráticas permanece como uma grandedificuldadea ser enfrentada, especialmentena intrincada composição entre o respeito à liberdade individual eà igualdade. 0 primeiro termo pressupõe, em sua essência, que a desigualdade 
porventura existente entre os sujeitos autônomos deve não apenas ser respeitada, mas também estimulada, na medida em que propicia um incremento enriquecedor no numero de vozes nos agrupamentos humanos laicos e plurais. Esta posição teórica tem como importantes expoentes os pensadores H. Tristam Engel hardt Jr. e Richard N ozick, os quais defendem uma ampla liberdade do indivíduo, com mínima intervenção do Estado, quando muito para garantir, justamente, a liberdade individual ${ }^{102,103}$. N este âmbito, cabe a interrogação sobre o grau de autonomia efetiva de pessoas que, por conta de um estado de profunda desigualdade - como no caso da sociedade brasileira ${ }^{104,105}$ - , encontramse alijadas das mínimas condições para se manterem dignamente. Estas e outras indagações ganham contornos bastante próprios no seio das democracias contemporâneas, como demarcado na notável crítica articulada por A lexis de Tocqueville ${ }^{106}$ :

O individual ismo origina-seda democracia [...] $\mathrm{N}$ a medida em que as condições se tornam iguais, aumenta o número de indivíduos que, já não sendo ricosou poderososo bastantepara exercer grande influência sobre o destino de seus semel hantes, conservaram ou adquiriram, não obstante, instrução ebens suficientes para bastar-sea si mesmos. $\mathrm{N}$ ada devem a ninguém; habituam-se a considerar-se sempre de forma isolada e até imaginam que seu destino esteja em suas mãos. Assim, a democracia não só leva cada homem a esquecer-se de seus antepassados, mas também Ihe esconde seus descendentes e o separa de seus contemporâneos; sem cessar, ela o traz de volta a si mesmo, ameaçando enclausurá- lo inteiramente na solidão de seu próprio coração ${ }^{106}$.

0 excerto de Tocquevilleapresenta as interfaces da inserção dos indivíduos no ordenamento democrático, chegando a comentar criticamente a existência - questionável - de um certo senso de empoderamento de sua própria jornada de vida. A contrapartida deste "efeito adverso" individualismo - seria a ideologia coletivista, segundo a qual o coletivo alcançaria uma substancialidade, capaz de justificar sua prioridade sobre os anseios dos indivíduos tomados isoladamente ${ }^{107}$. Este plano de discussão vem se estabelecendo desdeo século XIX - como na distinção durkheimiana entresolidariedade mecânica e solidariedadeorgânica, respectivamentereferidas aos estágios iniciais (prioridade no indivíduo) e maduros (prioridade no coletivo, em um sentido orgânico, formulado em termos de uma metáfora biológica) das organizações sociais ${ }^{108}-$, acirrando-se, especialmente, após a Revolução Russa de $1917^{109}$. De fato, no século XX, as reflexões e contestações agudizaram-se em torno de matizes predominantementeideológicos, estabelecidos na oposi ção entre coletivismo (identificado com o holismo) - orientação que ressalta 0 cumprimento das obrigações com os demais, no sentido de seguir as determinações do grupo de pertença, o qual é considerado mais importante do que a própria pessoa em $\mathrm{si}^{110}$ - e individualismo - concepção que enfatiza a individualidade, tratada em termos de independência das demais pessoas e dos grupos, sem que haja constituição de um genuíno senso depertencimento ${ }^{111}$.

Sob este acirrado debate entre individualismo e coletivismo, como compor, sem fundamentalismos e extremismos, autonomia e justiça, de modo que os sujeitos possam desempenhar sua (possível) autodeterminação no sentido de atingir genuínas escolhas para sua própria vida? Uma vez mais, neste contexto, a autonomia aparece como um "devaneio" inalcançável, em suas diferentesinstâncias:

A autonomia econômica é uma ficção, num mundo em queas principais deci sões macroeconômicas são tomadas por bancos centrais estrangeiros e por conselhos de administração de empresas transnacionais, em que a volatilidade dos mercados financeiros impede qualquer planejamento a longo prazo, e em que as inovações tecnológicas têm origem externa. A autonomia política se torna relativa, quando se leva em conta que as decisões políticas que mais diretamente afetam nossas vidas foram tomadas fora de nossas fronteiras [...] a autonomia cultural éuma fraude para aqueles que ficam indefesos diante dos aparelhos ideológicos e que são meros consumidores passivos de bens culturais sobre cuja produção e distribuição não têm qualquer controle $e^{112}$.

Diante de todos estes paradoxos - determinação da realidade física/biológica, dos processos psíquicoseimpossibilidades conceituais para exercício da liberdade dentro de coordenadas sociais - seria ainda factível pensar em autonomia (mais propriamente, do indivíduo, para decidir sobre sua vida ou morte)?

Controvérsiasfinais: enfim, há escolha autônoma em relação à eutanásia?

A despei to de sua importância, o conceito de autonomia tem se mostrado bastante problemáti$\mathrm{CO}^{12}$, na medida em que sua formulação e aplica- 
ção têm redundado na produção de uma série de aporias - em diferentes planos de discussão , como se tentou demarcar ao longo desteensaio. As discussões ora entabuladas podem ser sumarizadas em dois grupos principais de indagações, a saber: (1) o determinismo absoluto e (2) a impossibilidade de resolver a tensão entreindividual ecoletivo.

A primeira questão, como visto, estána agenda da logomaquia filosófica desde a Antigüidade, o que demonstra as dificuldades para o seu tratamento conceitual. Na verdade, o modo segundo o qual a pergunta vem sendo formulada parece tornar impossível qualquer escapatória caracterizando, assim, uma aporia genuína no âmbito do pensamento e da cultura - , uma vez que (1) o acaso esvazia a possibilidade de fundação da ciência, na medida em que às leis naturais sempre se oporá o evento fortuito, inviabilizando assim sua aplicação irrestrita - mesmo no território da mecânica quântica, há autores que questionam a indeterminação, mantendo a crença de que 0 avanço do conhecimento permitirá 0 ocaso desta forma de probabilismo ${ }^{64}$ - e (2) a necessidade estrita torna a ética contemporânea impensável, na medida em que extingue a possibilidade deseagir livremente:

M as, se por outro lado eu não tiver a crença de que há uma certa margem de autonomia, que me dá condições de pensar, de refletir sobretudo (volto a citar o velho Kant, que dizia que todo homem, que quiser, tem condições de ser um legislador universal) - se eu não tiver essa crença, cairá por terra qualquer pretensão de poder realizar uma análise ética ${ }^{113}$.

Assim, em termos lógicos, aquiescer teoricamente ao acaso ou ao determinismo representaria uma adesão excludenteà possibilidadedeagir eticamente ou de conhecer [definitivamente] a realidade, respectivamente. Sem embargo, podese pensar uma via de escape para tal paradoxo, na medida em que se esvazia o núcleo do determinismo: a causalidade. Para isto, pode se recorrer, uma vez mais, a David Hume:

Quando olhamos para os objetos ao nosso redor e consideramos as operações das causas, não somos jamais capazes de identificar, em nenhum caso singular, nenhum poder ou conexão necessária, nenhuma qualidade que ligue o efei to à causa e torne o primeiro uma conseqüência infalível da segunda ${ }^{33}$.

A causalidade seria assim, para Hume, uma expressão do modo a partir do qual o ser humano articula as informações provindas do real, sem que nada possa ser afirmado em relação à sua existência. 0 que aqui entra em jogo é o sentimento decrença - acreditar que o "anterior" eo "posterior" são ligados por um "fio", a causalidade. Tal foi a constatação que permitiu a Kant estabelecer que as categorias a priori - como, por exemplo, a causalidade - , eram parte do "aparato cognitivo" do sujeito. Tal formulação desloca, claramente, o debate do determinismo. Se a causalidade não está "nas coisas" - ou seja, não pertence ao real - , então não faz sentido se perguntar sobre o determinismo, esvaziando-se assim a questão da existência, ou não, do livrearbítrio. Esta é uma "saída pela tangente", é bem verdade, representando, em última análise, uma alternativa para ir além de tal aporia.

0 segundo problema, as relações entreindivíduo e coletividade- ou, em outrostermos, entre autonomia ejustiça - , émais recente- um subproduto da modernidade -, mas igualmente complexo no seu manejo, como o esboçado no "quarto paradoxo". Entretanto, nos contextos em que a justiça possa ser compreendida como eqüidade - como em Aristóteles ${ }^{114}$ e Rawls ${ }^{115}$, por exemplo - alternativas podem ser pensadas, com propostas de equilíbrio entre os extremos de individualistas/egoístas e coletivistas/totalitários. Nesta perspectiva se incluem os trabalhos de Amartya Sen, economista indiano que pensou uma igualdade complexa ${ }^{116,117}$, na qual é possível equacionar, de modo notável, autonomia e justiça, ao se abolir a determinação heterônoma do que deve ser igualado, passando a voz de escolha ao titular da própria existência. A despeito disto, pode-se reiterar todas as interrogações acerca da possibilidade de escolhas livres e genuínas e, ademais, as concepções senianas de capacidades efuncionamentos pressupõem uma radical transformação social, capaz de al cançar horizontes muito mais amplos, "quase" revolucionários, difíceis de serem concebidos na hodierna ordem mundial.

Após todas estas digressões - nas quais se procurou tensionar, virtual mente esgarçar, o conceito de autonomia, expondo suas aporias e inconsistências - o que se pode pensar sobre a livre decisão de pleitear para si a eutanásia?

Esta questão não pode ser respondida, sem que isto, no entanto, seja justificativa para se impedir a ação. Na verdade, em meio a tantas e tamanhas - dificuldades para se sustentar a autonomia, o quese pode fazer éreconhecer inequivocamente que (1) a eutanásia poderá se tornar uma saída para aquele humano que sofre de modo insuportável, e (2) que sua concretização dependerá do acolhimento incondicional por parte de um outro - um profissional de saúde, 
por exemplo - , capaz dereconhecer a dimensão do martírio enquanto lídima morte em vida. $\mathrm{E}$ esta acolhida, um genuíno ato de compaixão, pode ser radical a ponto de se reconhecer que 0 desejo de morrer - determinado ou não - de um sujeito, para o qual sua condição existencial se torna extenuante demais, é suficientemente valioso para que não se considere gravemente a possibilidade de concretizá-lo... mesmo quetudo o mais - a vida, o nascer e o morrer, o pensar e o sentir - , não passem de uma profunda e incógnita ficção...

\section{Colaboradores}

R Siqueira-Batista e FR Schramm caminharam lado a lado, como hoplitas, por todas as etapas da construção do artigo.

\section{Referências}

1. Schramm FR. A questão da definição da morte na eutanásia e no suicídio assistido. 0 M undo da Saúde 2002; 26(1):178-183.

2. Chapple A, Ziebland S, M cPherson A, Herxheimer A. What people close to death say about euthanasia and assisted suicide: a qualitative study. J M ed Ethics 2006; 32(12):706-10.

3. Kottow M. Introducción a la bioética. Santiago: Universitária; 1995.

4. Suetônio. A vida dos doze Césares. $2^{\mathrm{a}}$ ed. São Paulo: Prestígio; 2002.

5. Siqueira-Batista R, Schramm FR. Conversações sobre a "boa morte": 0 debate bioético acerca da eutanásia. Cad Saúde Pública 2005; 1(1):111-119.

6. Schramm FR. Por qué la definición de muerte no sirve para legitimar moralmente la eutanasia y el suicidio asistido? Perspectivas Bioéticas 2001; 6(11):43-54.

7. Beauchamp TL, Childress JF. Princípios de ética biomédica. São Paulo: Loyola; 2002.

8. Costa CRBSF, Siqueira-Batista R. As teorias do desenvolvimento moral e o ensino médico: uma reflexão pedagógica centrada na autonomia do educando. Rev Bras Edu Med 2004; 28(3):242-250.

9. Schramm FR. A autonomia difícil. Bioética 1998; 6(1):27-37.

10. Segre M, Leopoldo e Silva F, Schramm FM . O contexto histórico, semântico e filosófico do princípio de autonomia. Bioética 1998; 6(1):15-26.

11. Braz M. Autonomia: onde mora a vontade livre? In: Carneiro F, organizador. A moralidade dos atos científicos. Rio de Janeiro: Fiocruz; 1999.

12. Homan RW. Autonomy reconfigured. Perspec Biol M ed 2003; 46(1):96-108.

13. Kottow M. Enseñando las paradojas de la autonomía. Rev Bras Edu M ed 2000; 24(3):40-45.

14. Siqueira-Batista R, Schramm FR. Eutanásia: pelas veredas da morte e da autonomia. Rev C S Col 2004; 9(1):31-41. 
15. Cardoso C. A cidade estado antiga. São Paulo: Ática; 1987.

16. Mondolfo R. $O$ homem na cultura antiga. São Paulo: M estre Jou; 1968.

17. Jaeger W. Paidéia: a formação do homem grego. $3^{\mathrm{a}}$ ed. São Paulo: Martins Fontes; 1995.

18. Reale G. História da filosofia antiga. Volume I. São Paulo: Loyola; 1999.

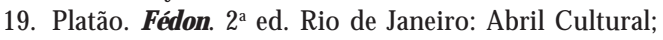
1979.

20. Siqueira-Batista R, Schramm FR. Platão e a medicina. História, Ciências, Saúde - M anguinhos 2004; 11(3): 619-634.

21. Jaeger W. Cristianismo primitivo e paidéia grega. Lisboa: Edições 70; 1991.

22. Jauss HR. Pour une esthétique de la réception. Paris: Gallimard; 1978.

23. Santo Agostinho. 0 livre arbítrio. São Paulo: Paulus; 1995.

24. Arendt H. A vida do espírito. Rio de Janeiro: Relume Dumará/UFRJ; 1995.

25. Gilson E. A filosofia na Idade M édia. São Paulo: Martins Fontes; 1998.

26. Rios AR. A vontade entre a Grécia clássica e o Cristianismo. In: De Boni LA, organizador. Idade M édia: ética e política. $2^{\text {a }}$ ed. Porto Alegre: EDIPUCRS; 1996.

27. Dumont L. Essai sur l'individualisme. Paris: Sueil; 1983.

28. Gandillac M. Gêneses da modernidade. Rio de Janeiro: Editora 34; 1995.

29. Rossi P. A ciência e a filosofia dos modernos. São PauIo: UNESP; 1992.

30. Descartes. Discurso do método. São Paulo: EuropaAmérica; 1977.

31. Descartes. M editações metafísicas. São Paulo: Martins Fontes; 2000

32. Descartes. Les principes de la philosophie. Paris: Gallimard; 1952.

33. Hume D. Investigação sobre o entendimento humano. São Paulo: UNESP; 1999.

34. Kant I. Crítica da razão pura. Rio de Janeiro: Edições de Ouro; 1966.

35. Weber M. Die protestantische Ethik und der Geist des Kapitalismus. Gesammelte Aufsätze zur Religionsoziologie. Vol I. Frankfurt a/M ain: Suhrkamp; 1973.

36. Kant I. Kritik der praktischen Vernunft. Riga: Hartknoch; 1787.

37. Kant I. Fundamentação da metafísica dos costumes. Lisboa: Edições 70; 1960.

38. Pascal G. 0 pensamento de Kant. $7^{\text {a }}$ ed. Petrópolis: Vozes; 2001.

39. Bornheim GA. As medidas da liberdade. In: Novaes A, organizador. 0 avesso da liberdade. São Paulo: Companhia das Letras; 2002.

40. Reale G. História da filosofia antiga. Volume V. São Paulo: Loyola; 1999.

41. Kirk GS, Raven JE, Schofield M. Os filósofos présocráticos: história crítica com seleção de textos. Lisboa: Fundação Calouste Gulbenkian; 1994

42. Legrand G. Os pré-socráticos. Rio de Janeiro: Jorge Zahar Editor; 1997.
43. Siqueira-Batista R. Deuses e homens. São Paulo: Landy; 2003.

44. Sófocles. A trilogia tebana. $5^{\mathrm{a}}$ ed. Rio de Janeiro: Jorge Zahar; 1989.

45. Laín Entralgo P. La medicina hipocrática. Madri: Alianza Editorial; 1987.

46. Lucrèce. De la nature. Paris: Belles Lettres; 1978.

47. Siqueira-Batista R. Acaso e descontinuidade no De rerum natura de Lucrécio. AnaLógos 2002; 2:224-230.

48. Deleuze G. Lógica do sentido. São Paulo: Perspectiva; 1998.

49. Marx K. Diferença entre as filosofias da natureza em Demócrito e Epicuro. São Paulo: Global; 1980.

50. Gazolla R. O ofício do filósofo estóico. São Paulo: Loyola; 1999.

51. Mondolfo R. O pensamento antigo. Volume II. São Paulo: M estre Jou; 1965.

52. Diógenes Laêrtios. Vidas e doutrinas dos filósofos ilustres. Brasília: UnB; 1977.

53. Spinoza B. Ética - demonstrada à maneira dos geôme tras. São Paulo: Martin Claret; 2003.

54. Scruton R. Espinosa. São Paulo: Loyola; 2001

55. Vargas M. História da matematização da natureza. Estudos Avançados 1996; 10(28):249-276

56. Newton I. Mathematical principles of natural philosophy. Chicago: Britannica Great Books; 1978.

57. Laplace PS. O euvres completes. Paris: Gauthier-Villars; 1884.

58. Ruelle D. Acaso e caos. São Paulo: UNESP; 1993.

59. Bohr N. Física atômica e conhecimento humano. Rio de Janeiro: Contraponto; 1995.

60. Heisenberg W. A parte e o todo. Rio de Janeiro: Contraponto; 1996.

61. Capra F. O tao da física. São Paulo: Cultrix; 1983.

62. Siqueira-Batista R, Siqueira-Batista R, Corrêa AD, Sforza-de-Almeida MP. Ensaios sobre o átomo. Rio de Janeiro: Litteris; 2000.

63. Bunge M. Física e filosofia. São Paulo: Perspectiva; 2000.

64. Stewart I. Será que Deus joga dados? A matemática do caos. Rio de Janeiro: Jorge Zahar; 1991.

65. Atlan H. Ruído e determinismo: diálogos espinosistas entre antropologia e biologia. Maná 2003; 9(1):123-137

66. Aleksandrowicz AM C, M inayo MCS. Humanismo, liberdade e necessidade: compreensão dos hiatos cognitivos entre ciências da natureza e ética. Rev C S Col 2005; 10(3):513-526.

67. Lent R. Cem bilhões de neurônios. 2ª ed. São Paulo: Atheneu; 2005.

68. Solso RL. Ciências da mente e do cérebro no século XXI. Brasillia: UnB; 2004.

69. Damásio A. Como o cérebro cria a mente. Scientific American Brasil 2004; 4:6-9.

70. Pensrose R. Shadows of the mind. Oxford: Oxford University Press; 1994

71. Posner MI, Raichle ME. Images of mind. New York: Scientific American Library; 1994.

72. Greene J, Cohen J. For the law, neuroscience changes nothing and everything. Phil Trans R Soc London 2004; 359:1775-1785. 
73. Peixoto JCF, Santos EA, Paulino AT, Fraia CGPP, Borlot PEW, Santos SS, Gomes AP. Aspectos etiopatogênicos da doença de Huntington. J Bras M ed 2005; 88(3):47-51.

74. Palácios M, Rego S, Schramm FR. A regulamentação brasileira em ética em pesquisa envolvendo seres humanos. In: Medronho RA, organizador. Epidemiologia. São Paulo: Atheneu; 2002.

75. Penchaszadeh VB. Problemas éticos do determinismo genético. Bioética 2004; 12(1): 61-68.

76. Menck CFM, Sluys M AV. Fundamentos de biologia molecular. In: M ir L, organizador. Genômica. São Paulo: Atheneu; 2004.

77. Schramm FR. Algumas controvérsias semânticas e morais acerca do acesso e do uso do genoma humano. In: Carneiro F, Emerick MC, organizadores. A ética e o debate jurídico sobre acesso e uso do genoma humano. Rio de Janeiro: Fiocruz; 2000.

78. Schramm FR. A terceira margem da saúde. Brasília: UnB; 1996.

79. Pena SDJ. M edicina genômica. In: M ir L, organizador. Genômica. São Paulo: Atheneu; 2004.

80. M endes EG. Determinismo e liberdade da vontade: o enfoque biológico. Estudos Avançados 1998; $12(32): 213-224$.

81. Schopenhauer A. O M undo como vontade e representação. Rio de Janeiro: Contraponto; 2001.

82. Barbosa J. Schopenhauer. Rio de Janeiro: Jorge Zahar; 2003.

83. Janaway C. Schopenhauer. São Paulo: Loyola; 2003.

84. Zentner M. Die flucht ins vergessen. Darmstadt: Wissenschaftliche Buchgesellschaft; 1995.

85. Schopenhauer A. Sobre o fundamento da moral. São Paulo: M artins Fontes; 2001.

86. Nietzsche F. A genealogia da moral. São Paulo: Brasiliense; 1987.

87. Nietzsche F. Além do bem e do mal. São Paulo: Companhia das Letras; 1992.

88. Birman J. Estranhas passagens, entre estesia e alteridade: sobre a problemática do sujeito no discurso freudiano. Cadernos de Subjetividade 1995; 3(2):211242.

89. Laplanche J, Pontalis JB. Vocabulário da psicanálise. Lisboa: M artins Fontes; 1970.

90. Garcia-Roza LA. Freud e o inconsciente. $4^{a}$ ed. Rio de Janeiro: Jorge Zahar; 1988.

91. Freud S. 0 ego e o id. In: Freud S. Obras psicológicas completas. Volumes IV e V. Rio de Janeiro: Imago; 1974.

92. Freud S. O inconsciente. In: Freud S. Obras psicológicas completas. Volume XIV. Rio de Janeiro: Imago; 1974.

93. Lacan J. Écrits. Paris: Seuil; 1966.

94. Freud S. A interpretação dos sonhos. In: Freud S. O bras psicológicas completas. Volumes IV e V. Rio de Janeiro: Imago; 1974.

95. Ricoeur P. Da interpretação: ensaio sobre Freud. Rio de Janeiro: Imago; 1977.
96. Freud S. Conferência XXXI: A dissecção da personalidade psíquica. In: Freud S. Obras psicológicas completas. Volume XXII. Rio de Janeiro: I mago; 1974.

97. Freud S. Totem e tabu. In: Freud S. O bras psicológicas completas. Volume XIII. Rio de Janeiro: Imago; 1974.

98. Fulgencio L. Comentários críticos das referências textuais de Freud a Kant. Psicologia USP 2001; 12(1):49-87.

99. Ferraz FC. A eternidade da maçã: Freud e a ética. São Paulo: Escuta; 1994.

100. Hegel GWF. A fenomenologia do espírito. Petrópolis: Vozes; 1992.

101. Lacan J. El Seminario. Libro XI. Los cuatro conceptos fundamentales del psicoanálisis. Barcelona: S. Barral; 1977.

102. Engelhardt Jr. HT. The foundations of bioethics. $2^{\text {nd }}$ ed. London: Oxford University Press; 1996.

103. Nozick R. Anarquia, Estado e utopia. Rio de Janeiro: Jorge Zahar; 1991.

104. M inayo M CS. Estrutura e sujeito, determinismo e protagonismo histórico: uma reflexão sobre a práxis da saúde coletiva. Rev C S Col 2001; 6(1):7-19.

105. Siqueira-Batista R. M iséria. $3^{a}$ ed. Rio de Janeiro: KroaArt; 2007.

106. Tocqueville A. A democracia na América. Belo Horizonte: Itatiaia; 1977

107. Oliva A. Conhecimento e liberdade. $2^{\mathrm{a}}$ ed. Porto Alegre: EDIPUCRS; 1999.

108. Durkheim É. La división del trabajo social. Madri: Akal Editor; 1982.

109. Nivat G. Elementos milenaristas na Revolução Russa. Estudos Avançados 1998; 12(32):57-68.

110. Gouveia VV, Clemente M, Vidal MA. España desde dentro: el individualism y el colectivismo como rasgos diferenciadores de las comunidades autónomas. Sociedad y Utopia. Revista de Ciencias Sociales 1998; 11:167-179.

111. Gouveia VV, Andrade JM, Milfont TL, Santos WS. Dimensões normativas do individualismo e coletivismo: é suficiente a dicotomia pessoal vs. social? Psicol: Reflex Crít 2003; 16:223-234.

112. Rouanet SP. Democracia mundial. In: Novaes A, organizador. 0 avesso da liberdade. São Paulo: Companhia das Letras; 2002.

113. Segre M. Ética em saúde. In: Palácios M, Martins A, Pegoraro O, organizadores. Ética, ciência e saúde. Petrópolis: Vozes; 2002.

114. Aristóteles. Ética a Nicômaco. Braślia: UnB; 1985.

115. Rawls J. U ma teoria da justiça. São Paulo: Martins Fontes; 1997.

116. Siqueira-Batista R, Schramm FR. A saúde entre a iniqüidade e a justiça: contribuições da igualdade complexa de Amartya Sen. Rev C S Col 2005; 10(1):129-142.

117. Sen A. Desigualdade reexaminada. Rio de Janeiro: Record; 2001.

Artigo apresentado em 23/11/2005

Aprovado em 30/06/2006

Versão final apresentada em 05/02/2007 
